\title{
COVID-19 outbreak impact in Spain: A role for tobacco smoking?
}

\author{
Javier C. Vázquez', Diego Redolar-Ripol/2
}

\section{Dear Editor,}

Coronavirus disease 2019 (COVID-19) is an infectious disease provoked by severe acute respiratory syndrome coronavirus 2 (SARS-CoV-2 $)^{1}$. The virus typically spreads from person to person via respiratory droplets produced during coughing, and common symptoms include fever, cough, and shortness of breath ${ }^{2}$. The COVID-19 outbreak was initially identified in Wuhan, capital of Hubei Province, China, in December 2019, and has since spread rapidly globally. It was declared a pandemic on 11 March 2020 by the World Health Organization (WHO) ${ }^{3}$. As of 26 March 2020, a total number of 480446 cumulative cases of COVID-19 have been reported in 175 countries and regions, including 22030 confirmed deaths, the majority of which have been reported in Italy (7503), Spain (4089) and China $(3169)^{4}$. In Spain, as of 25 March 2020, most of those who have died were elderly, about $96 \%$ of deaths were in those over 60 years old, and $45 \%$ had pre-existing health conditions including cardiovascular disease $(31 \%)^{5}$.

With 120859 deaths in 2018, cardiovascular disease (CVD) is the leading cause of death in Spain $(28.3 \%)^{6}$. Sex-disaggregated data for CVD in Spain show differences in mortality between men $(46.3 \%)$ and women $(53.7 \%)^{6}$. Surprisingly, although men (51\%) and women (49\%) are getting infected by COVID-19 at similar rates, men have been dying from COVID-19 at a significantly higher rate $(4.4 \%)$ than women $(2.5 \%)$, and the sex differences regarding vulnerability in those with COVID-19 and preexisting CVD seem to be again reflected in men $(35 \%)$ and women $(26 \%)^{5}$.

Emerging evidence suggests that these discrepancies could potentially be due to gendered differences such as patterns and prevalence of smoking. In this regard, approximately $10 \%$ of cardiovascular disease is globally attributed to smoking, with smoking prevalence in 2017 among men in Spain being approximately $25.6 \%$ but only $18.8 \%$ in women ${ }^{8}$.

Could smoking influence the gender-based impact of the outbreak? And the impact itself?

These hypotheses could be coupled with new available evidence from the WHO on COVID-19, warning that a weaker cardiovascular system among COVID-19 patients with a history of tobacco use could make such patients susceptible to severe symptoms, thereby increasing the chance of death ${ }^{9}$. According to the recent (18 March 2020) systematic review of Vardavas and Nikitara ${ }^{10}$, smoking is most likely associated with the negative progression and adverse outcomes of COVID-19.

Accordingly, we recommend that public health messages and behavioural interventions coming from the Spanish government that focus on how to spread and flatten the COVID-19 infection curve should also consider available evidencebased high-quality smoking cessation advice.

\section{AFFILIATION \\ 1 NutriNeuro, Bordeaux \\ Neurocampus, Bordeaux, \\ France \\ 2 Cognitive NeuroLab, Faculty of Health Sciences, \\ Universitat Oberta de \\ Catalunya, Barcelona, Spain \\ CORRESPONDENCE TO \\ Diego Redolar-Ripoll. \\ Cognitive NeuroLab, \\ Faculty of Health Sciences, \\ Universitat Oberta de \\ Catalunya, Rambla del \\ Poblenou 156, 08018, \\ Barcelona, Spain. E-mail: \\ deredolar@uoc.edu \\ ORCID ID: https://orcid. \\ org/0000-0001-6922-2822 \\ KEYWORDS \\ smoking, tobacco, COVID-19, coronavirus, sex differences}

Received: 26 March 2020 Accepted: 1 April 2020 


\section{REFERENCES}

1. World Health Organization. Naming the coronavirus disease (COVID-19) and the virus that causes it. https://www.who. $\mathrm{int/emergencies/diseases/novel-coronavirus-2019/technical-guidance/naming-the-coronavirus-disease-(covid-2019)-}$ and-the-virus-that-causes-it. Published February, 2020. Accessed March 25, 2020.

2. World Health Organization. Q\&A on coronaviruses (COVID-19). https://www.who.int/news-room/q-a-detail/q-acoronaviruses. Published March, 2020. Accessed March 25, 2020.

3. World Health Organization. WHO Director-General's opening remarks at the media briefing on COVID-19. https:// www.who.int/dg/speeches/detail/who-director-general-s-opening-remarks-at-the-media-briefing-on-covid-19---11march-2020. Published March, 2020. Accessed March 25, 2020.

4. Johns Hopkins University. Coronavirus COVID-19 Global Cases by the Center for Systems Science and Engineering (CSSE) at Johns Hopkins University (JHU). https://www.arcgis.com/apps/opsdashboard/index.html\#/ bda7594740fd40299423467b48e9ecf6. Published March, 2020. Accessed March 25, 2020.

5. Instituto de Salud Carlos III, Centro Nacional de Epidemiología, Red Nacional de Vigilancia Epidemiológica. Informe sobre la situación de COVID-19 en España. https://www.isciii.es/QueHacemos/Servicios/VigilanciaSaludPublicaRENAVE/ EnfermedadesTransmisibles/Documents/INFORMES/Informes\%20COVID-19/Informe\%20n\%C2\%BA\%2015.\%20 Situaci\%C3\%B3n\%20de\%20COVID-19\%20en\%20Espa\%C3\%B1a\%20a\%2025\%20marzo\%20de\%202020.pdf. Published March, 2020. Accessed March 25, 2020.

6. Instituto Nacional de Estadística. Defunciones según la Causa de Muerte: Año 2018. https://www.ine.es/prensa/ edcm_2018.pdf. Published December, 2019. Accessed March 25, 2020.

7. World Health Organization, World Heart Federation, World Stroke Organization. Global atlas on cardiovascular disease prevention and control. Mendis S, Puska P, Norrving B, eds. Geneva: World Health Organization; 2011. https://www. who.int/cardiovascular_diseases/publications/atlas_cvd/en/. Accessed March 25, 2020.

8. Instituto Nacional de Estadística. Determinantes de salud (consumo de tabaco, exposición pasiva al humo de tabaco, alcohol, problemas medioambientales en la vivienda). https://www.ine.es/ss/Satellite?L=es_ES\&c=INESeccion_C\&cid= 1259926698156\&p=1254735110672\&pagename=ProductosYServicios\%2FPYSLayout. Published October, 2021. Accessed March 25, 2020.

9. World Health Organization. Tobacco and waterpipe use increases the risk of suffering from COVID-19. http://www.emro. who.int/tfi/know-the-truth/tobacco-and-waterpipe-users-are-at-increased-risk-of-covid-19-infection.html. Published March, 2020. Accessed March 25, 2020.

10. Vardavas CI, Nikitara K. COVID-19 and smoking: A systematic review of the evidence. Tob Induc Dis. 2020;18(March). doi:10.18332/tid/119324

CONFLICTS OF INTEREST

The authors have completed and submitted the ICMJE Form for Disclosure of Potential Conflicts of Interest and none was reported.

FUNDING

There was no source of funding for this research.

PROVENANCE AND PEER REVIEW

Not commissioned; internally peer reviewed. 